\title{
Expression of mRNA encoding IGF-I, IGF-II and type 1 IGF receptor in bovine ovarian follicles
}

\author{
D G Armstrong, C G Gutierrez, G Baxter, A L Glazyrin, \\ G E Mann ${ }^{1}$, K J Woad, C O Hogg and R Webb ${ }^{2}$ \\ Division of Integrative Biology, Roslin Institute (Edinburgh), Roslin, Midlothian EH25 9PS, UK \\ ${ }^{1}$ Division of Animal Physiology, School of Biological Sciences, University of Nottingham, Sutton Bonington Campus, Loughborough, \\ Leicstershire LE12 5RD, UK \\ ${ }^{2}$ Division of Agriculture and Horticulture, School of Biological Sciences, University of Nottingham, Sutton Bonington Campus, Loughborough, \\ Leicstershire LE12 5RD, UK \\ (Requests for offprints should be addressed to D G Armstrong; Email: david.armstrong@bbsrc.ac.uk.)
}

\begin{abstract}
IGFs regulate gonadotrophin-stimulated proliferation and differentiation of granulosa and theca cells in vitro. However, the detailed pattern of mRNA expression of IGFs in bovine follicles remains controversial. The objectives of this study were therefore to describe the temporal and spatial pattern of expression of mRNA encoding IGF-I, IGF-II and the type 1 IGF receptor in bovine follicles in vivo. The expression of mRNA encoding IGF-II was detected in theca tissue from around the time of antrum formation up to and during the development of dominance. No IGF-II mRNA expression was detected in granulosa cells. In the majority of follicles we were unable to detect mRNA encoding IGF-I in either granulosa or theca tissue from follicles at any stage of development. Occasionally low amounts of mRNA encoding IGF-I were detected in the theca externa and connective tissue surrounding some follicles. Type 1 IGF receptor mRNA was detected in both granulosa and theca cells of preantral and antral follicles. Expression was greater in granulosa
\end{abstract}

tissue compared with theca tissue. We also measured IGF-I and -II mRNA in total RNA isolated from cultured granulosa and theca cells using reverse transcriptase PCR. In contrast to the in vivo results, IGF-II mRNA was detected in both granulosa and theca tissue. IGF-I mRNA was detected in theca tissue and in very low amounts in granulosa cells. Using a specific IGF-I RIA we were unable to detect IGF-I immunoreactivity in granulosa conditioned cell culture media. Using immunohistochemistry we detected IGF-I immunoreactivity in some blood vessels within the ovarian stroma. We conclude from these results that IGF-II is the principal intrafollicular IGF ligand regulating the growth of bovine antral follicles. In preantral follicles the expression of mRNA encoding type 1 IGF receptor but absence of endogenous IGF-I or -II mRNA expression, highlights a probable endocrine mechanism for the IGF regulation of preantral follicle growth.

Journal of Endocrinology (2000) 165, 101-113

\section{Introduction}

Insulin-like growth factors (IGFs) are putative regulators of follicular growth and enhance the actions of gonadotrophins on the ovary (Adashi \& Roban 1992, Guidice 1992, Armstrong \& Webb 1997, Webb \& Armstrong 1998). IGF-I stimulates granulosa and theca cell proliferation and differentiation in vitro in a number of mammalian species (Hammond et al. 1991, Adashi 1994, Spicer \& Echternkamp 1995, Gutierrez et al. 1997a, Campbell et al. 1998). In contrast IGF-II has not been as extensively studied as IGF-I; however, its effects on the proliferation and differentiation of granulosa cells have been demonstrated in a number of species including the pig and sheep (Hammond et al. 1991, Campbell et al. 1995, Monget \& Monniaux 1995).
The expression of mRNAs encoding IGF-I and -II in ovarian follicles is developmentally regulated in a speciesspecific manner (Armstrong \& Webb 1997, Webb \& Armstrong 1998). Although it has been clearly established that IGF-I is expressed in granulosa cells of rodents and pigs its expression in the ruminant remains controversial, with reports demonstrating both the presence (Spicer et al. 1993, Leewenberg et al. 1995, Spicer \& Echternkamp 1995, Yuan et al. 1998) and absence (Perks et al. 1995, 1999, Armstrong et al. 1998a) of mRNA encoding IGF-I in both bovine and ovine granulosa cells. Similarly, although Spicer et al. (1993) detected IGF-I immunoreactivity in bovine granulosa cell conditioned medium we were unable to demonstrate the presence of immunoreactive IGF-I in bovine granulosa cell conditioned culture medium after the removal of endogenous 
IGF-binding proteins (IGFBPs) by chromatography under acidic conditions (Gutierrez et al. 1997b). To shed light on this controversy and provide further information on the role of the IGF system in the bovine ovary we have examined the patterns of expression of mRNAs encoding both the IGFs and their receptor (type 1 IGF receptor) during folliculogenesis in vivo. We also examined the expression of IGF-I and -II mRNA in bovine granulosa and theca cells in vitro.

\section{Materials and Methods}

\section{Materials}

Cell culture material was obtained from GIBCO BRL Life Technologies Ltd, Paisley, Renfrewshire, UK. Recombinant human Long R3 IGF-I (LR3-IGF-I, media grade) and recombinant human IGF-I were purchased from Gropep Pty Ltd (Adelaide, SA, Australia). The US Department of Agriculture generously donated folliclestimulating hormone (FSH) (USDA-bFSH-I-2; potency $854 \mathrm{IU} / \mathrm{mg}$; no cross reactivity with USDA-bLH-B-5 using USDA-5 antiserum) and the National Institute of Arthritis, Diabetes and Digestive and Kidney Diseases (Torrance, CA, USA) generously donated luteinizing hormone (LH) (NIDDK-oLH-S26; potency $2.3 \mathrm{IU} / \mathrm{mg}$; FSH contamination $<0 \cdot 5 \%$ by weight).

\section{Collection of tissue and characterization of follicles}

Experiment 1 Ovaries $(n=6)$ were obtained from six cows from the local abattoir. They were either processed directly for cell culture or divided into blocks. The diameters of follicles on the surface of the ovaries were measured before the blocks were snap frozen in liquid nitrogen and stored at $-70{ }^{\circ} \mathrm{C}$ until required for in situ hybridization. Follicles were classified as healthy, atretic or grossly atretic as described previously (Armstrong et al. 1998b). Expression of mRNAs encoding IGF-I and -II and type 1 IGF receptor was determined by in situ hybridization in 65 follicles from six ovaries. The follicle numbers were made up of 33 small $(1-4 \mathrm{~mm})$ follicles (18 healthy, 10 atretic and 5 grossly atretic), 34 medium $(4-8 \mathrm{~mm}$ ) follicles ( 8 healthy, 16 atretic and 10 grossly atretic) and 8 large $(>8 \mathrm{~mm})$ follicles $(5$ healthy, 2 atretic and 1 grossly atretic).

Experiment 2 Ovaries were collected from lactating Holstein-Friesian cows $(n=5)$ during the luteal phase of the oestrous cycle (on days 14, 16 and 18 following natural oestrus) and during the follicular phase (on day 20 following natural oestrus and 2 days after the initiation of luteolysis by the prostaglandin F2 $\alpha$ analogue cloprostenol (Estrumate; Schering-Plough Animal Health, Welwyn Garden City, UK). Immediately following slaughter the reproductive tract was removed and transported to the laboratory where ovaries were stored at $4{ }^{\circ} \mathrm{C}$ until processing as for the previous experiment. Blocks containing the largest follicles (15-20 $\mathrm{mm}$ diameter) were analysed by in situ hybridization.

\section{Granulosa and theca primary cell cultures}

Granulosa and theca cells from medium-sized (4-8 mm) gonadotrophin-dependent follicles were isolated and pooled. Granulosa cells $\left(3 \times 10^{6}\right.$ viable cells $)$ were plated in $10 \mathrm{ml}$ culture medium containing testosterone $(0 \cdot 1 \mu \mathrm{mol} / \mathrm{l})$ in $50 \mathrm{ml}$ culture bottles for up to $96 \mathrm{~h}$, with the medium changed after $48 \mathrm{~h}$, as described previously (Gutierrez et al. 1997a, Armstrong et al. 1998b). Granulosa cell cultures were supplemented with insulin $(10 \mathrm{ng} / \mathrm{ml})$, LR3-IGF-I $(10 \mathrm{ng} / \mathrm{ml})$ and either FSH $(0,1$ or $50 \mathrm{ng} / \mathrm{ml})$ or LH (0 or $100 \mathrm{ng} / \mathrm{ml}$ ).

After isolation of the granulosa cells, the remainder of the follicle wall was dispersed by enzymatic digestion. Isolated theca cells $\left(3 \times 10^{6}\right.$ viable cells $)$ were cultured in DMEM:Hams F12 (1:1) media $(10 \mathrm{ml})$ using $50 \mathrm{ml}$ culture bottles in the presence of insulin $(10 \mathrm{ng} / \mathrm{ml})$, IGF-I $(10 \mathrm{ng} / \mathrm{ml})$ and $\mathrm{LH}(0$ or $100 \mathrm{ng} / \mathrm{ml})$ for 4 days (Campbell et al. 1998).

\section{Reverse transcriptase PCR (RT-PCR)}

RNA was isolated from granulosa and theca cells after $96 \mathrm{~h}$ of culture using RNeasy spin columns (Qiagen Ltd, Crawley, West Sussex, UK) according to the manufacturer's instructions. Concentrations were estimated by absorbance at $260 \mathrm{~nm}$ and the samples were stored in RNase-free TE buffer at $-80{ }^{\circ} \mathrm{C}$ until required. The $\mathrm{A}_{260} / \mathrm{A}_{280}$ ratio for all RNA samples was $>1 \cdot 8$. Firststrand cDNA synthesis was carried out using Superscript II reverse transcriptase (Life Technologies Ltd) (Armstrong et al. 1998b). The primers used for the amplification of the IGF-I and -II mRNA transcripts were as shown in Table 1 and span the coding region of their respective mRNAs. Analysis was carried out on three separate cell cultures. Samples were heated to $94{ }^{\circ} \mathrm{C}$ for $3 \mathrm{~min}$ and amplified for 25 cycles $\left(94^{\circ} \mathrm{C}\right.$ for $1 \mathrm{~min} ; 55^{\circ} \mathrm{C}$ for $1 \mathrm{~min}$ and $72{ }^{\circ} \mathrm{C}$ for $1 \mathrm{~min}$ ). The final $72{ }^{\circ} \mathrm{C}$ incubation was continued for a further $4 \mathrm{~min}$. Reverse transcriptase blanks, RNA blanks and PCR blanks (no cDNA products) were included in each analysis. Aliquots $(5 \mu \mathrm{l})$ of each of the PCR reactions (total volume $20 \mu \mathrm{l}$ ) were analysed by electrophoresis on $4 \%$ agarose gels (NuSieve GTG Agarose; FMC Bioproducts, Rockland, ME, USA). Liver mRNA was included as a positive control and in all experiments reverse transcriptase blanks, RNA blanks and PCR blanks were negative. Identities of the PCR products were confirmed by restriction endonuclease digestion.

\section{IGF-I and -II and type 1 IGF receptor probes}

The homologous bovine IGF-II and type 1 IGF receptor probes were prepared following RT-PCR (see previous 
Table 1 Primer pairs used for PCR amplification of bovine IGF-II and type I IGF receptor cDNAs

\begin{tabular}{|c|c|c|c|}
\hline \multirow[b]{2}{*}{ Gene } & \multicolumn{2}{|c|}{ Size (bps) } & Primer \\
\hline & & & \\
\hline \multirow[t]{2}{*}{ IGF-I } & $196^{a}$ & Upstream primer & 5'-ССТСTGCGGGGCTGAGTTGGT-3' \\
\hline & & Downstream primer & 5'-CGACTTGGCGGGCTTGAGAGGC-3' \\
\hline \multirow[t]{2}{*}{ IGF-II } & $154^{\mathrm{b}}$ & Upstream primer & 5'-TCTGTGCGGCGGGGAGCTGGT-3' \\
\hline & & Downstream primer & 5'-AGTCTCCAGCAGGGCCAGGTCG-3' \\
\hline \multirow[t]{2}{*}{ Type 1 IGF receptor } & $189^{\mathrm{c}}$ & Upstream primer & 5'-CCAAGCTAAACCGGCTCAAC-3' \\
\hline & & Downstream primer & 5'-TTATTACCAAGCСТCССАC-3' \\
\hline
\end{tabular}

\footnotetext{
${ }^{a}$ Amplified product corresponds to position 156-351 of a bovine IGF-I cDNA (Fotsis et al. 1990).

${ }^{\mathrm{b}}$ Amplified product corresponds to position 7-160 of a bovine IGF-II CDNA (Brown et al. 1990).

CAmplified product is homologous to a partial bovine type I receptor cDNA clone (Sneyers et al. 1991) and

corresponds to position 2717-2905 of a human type 1 IGF receptor cDNA (Abbot et al. 1992).
}

section) using the primers described in Table 1. Amplified products were cloned into pGEM-T (Promega Ltd, Southampton, UK) using standard procedures and sequenced to confirm their identity and orientation within the plasmid. The IGF-II construct was linearized with NcoI and SP6 RNA polymerase was used to generate the antisense probe. The sense probe was generated using $\mathrm{T} 7$ RNA polymerase after linearizing the plasmid with NsiI. The type 1 IGF receptor construct was linearized with NotI, and T7 RNA polymerase was used to generate the antisense probe. The sense probe was generated using SP6 RNA polymerase after linearizing the plasmid with NcoI.

In ribonuclease protection assays RNase-protected bands of size 153 and 189 nucleotides were obtained using the bovine IGF-II and type 1 IGF receptor probes respectively.

The IGF-I probe used for in situ hybridization was the same as that described by Yuan et al. (1998) and spanned the coding region (bases 25-496) of a cDNA described by Tavakkol et al. (1988).

In situ hybridization

Frozen sections $(14 \mu \mathrm{m})$ were dehydrated, fixed and probed with ${ }^{35}$ S-labelled riboprobes (Armstrong et al. 1998b). After the final high stringency wash the sections were dipped in autoradiographic K2 photographic emulsion (Ilford Limited, Mobberley, Cheshire, UK) and exposed for 3 weeks at $4{ }^{\circ} \mathrm{C}$. Sections were then developed (Kodak D-19) and fixed (Ilford Hypam fixer) before staining in haematoxylin and eosin. The sections were finally mounted in DPX (R A Lamb, Sunbeam Road, London, UK) mountant before microscopic examination using both light- and darkfield illumination.

\section{Image analysis}

The intensity of the in situ hybridization signal was analysed using an NIH-Image analysis system (NIH, Bethesda, MD, USA). The number of graphic pixels occupied by silver grains (identified by a set grey threshold) within a defined area of the tissue section was counted and presented as a percentage of the total pixel number within the defined area. Background hybridization intensity, measured with the sense RNA probes was subtracted from the measurements obtained with the antisense probes to give the final hybridization signal. Within each follicle three separate fields were analysed for each probe. There was no difference $(P>0 \cdot 05)$ in hybridization intensity obtained with antisense and sense RNA probes within a non-expressing region of a tissue section. Under the conditions described here the hybridization signal was proportional to the length of time the slides were exposed to photographic emulsion for up to 3 weeks.

\section{IGF-I immunohistochemistry}

Immunohistochemistry was carried out as described previously. The rabbit anti-human IGF-I antiserum (Armstrong et al. 1990) was diluted 1:500 prior to use. After probing with primary antibody the sections were washed and stained using an anti-rabbit IgG biotin-avidin, peroxidase kit (Sigma, Poole, Dorset, UK) according to the manufacturer's instructions.

\section{Steroid and IGF-I RIAs}

Androstenedione and progesterone were measured according to the method described by Corrie et al. (1981). Oestradiol-17 $\beta$ was also measured by RIA as described by Webb et al. (1985). IGF-I was measured by RIA (Guttierrez et al. 1997b), after acid gel filtration to remove IGFBPs, using a rabbit polyclonal antibody raised against human recombinant IGF-I (Armstrong et al. 1990). The sensitivity of the assay was $22 \mathrm{pg}$ (two standard deviations from the minimum detectable level) and the intra- and interassay coefficients of variation were 13 and $8 \%$ respectively.

\section{Statistical analysis}

Steroid production by cell cultures is presented as mean \pm s.E.M. (three cultures with two replicates). The effects of FSH or LH (fixed effects) were analysed using a 


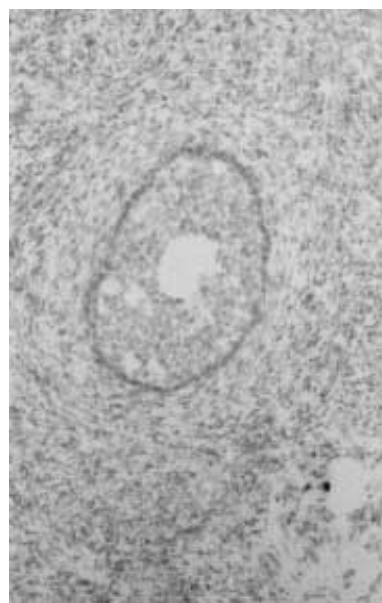

a

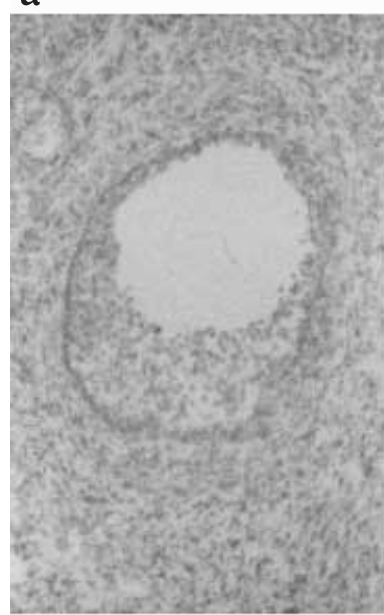

d

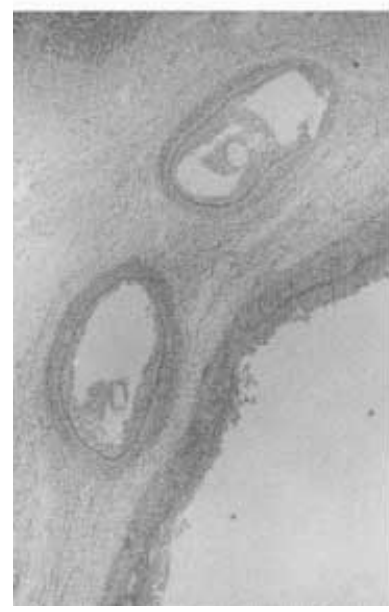

g

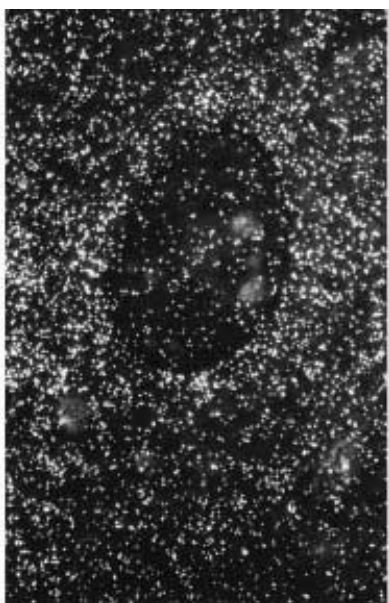

b

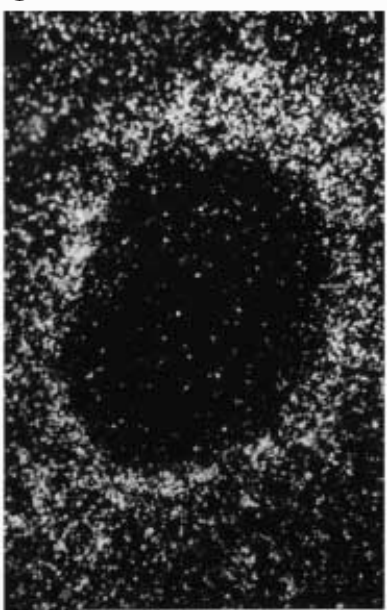

e

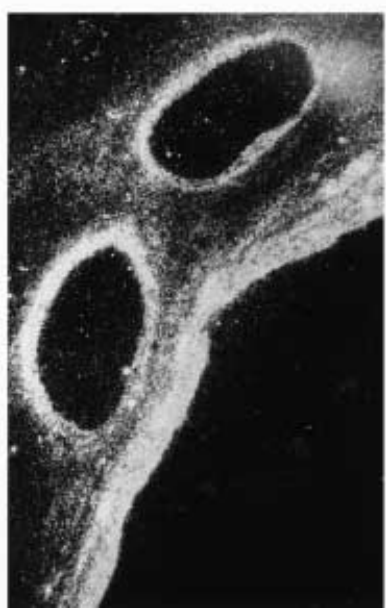

h

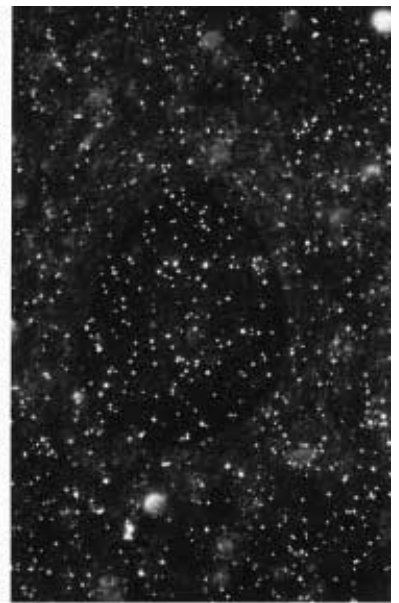

C

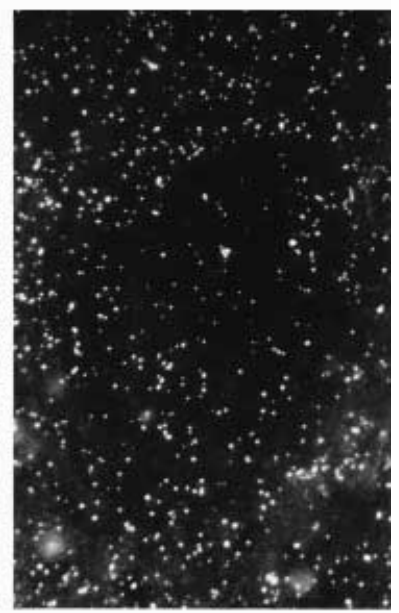

$\mathrm{f}$

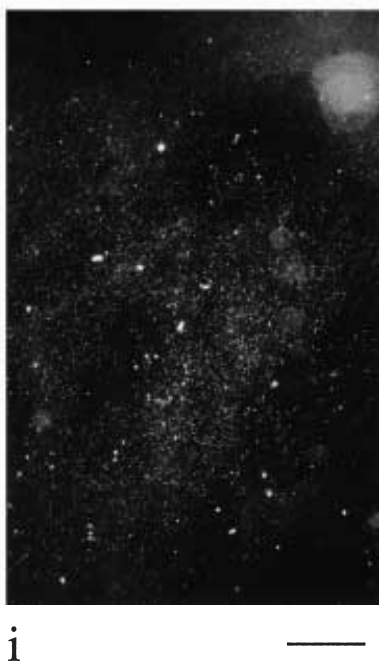

Figure 1 Lightfield (a, d and g) and darkfield (b, c, e, f, h and i) illumination of ovarian sections probed with an IGF-II antisense (b, e and $\mathrm{h}$ ) and sense (c, $\mathrm{f}$ and i) riboprobe. IGF-II mRNA expression is shown in theca tissue of a small follicle around the time of antrum formation $(\mathrm{a}-\mathrm{c})$, in theca tissue of a $0.5 \mathrm{~mm}$ diameter antral follicle $(\mathrm{d}-\mathrm{f})$ and in theca tissue in a group of three follicles $(2 \times 1 \mathrm{~mm}$ and $25 \mathrm{~mm}$ in diameter) $(\mathrm{g}-\mathrm{i})$. The bar represents $180 \mu \mathrm{m}(\mathrm{a}-\mathrm{f})$ and $450 \mu \mathrm{m}(\mathrm{g}-\mathrm{i})$. 


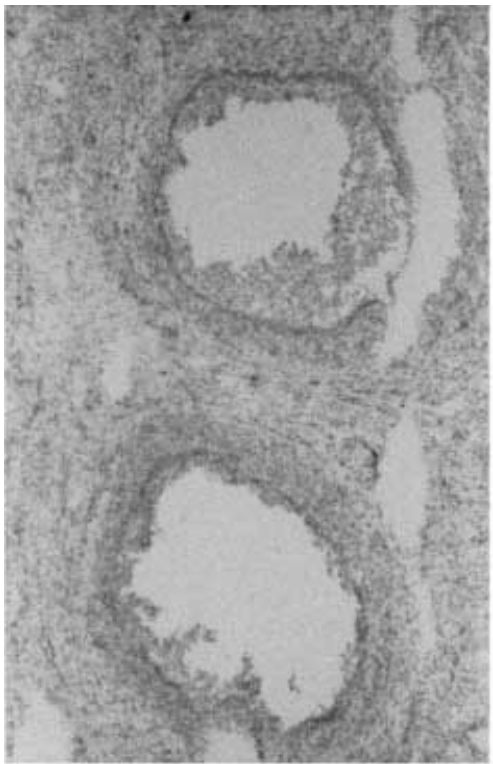

a

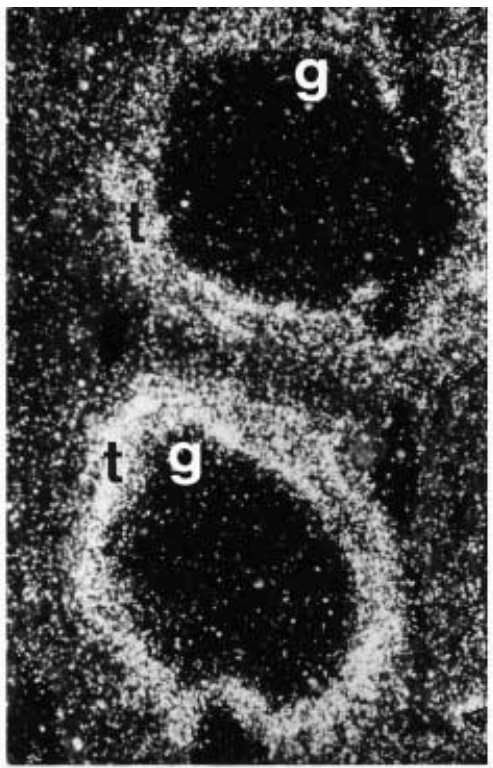

b

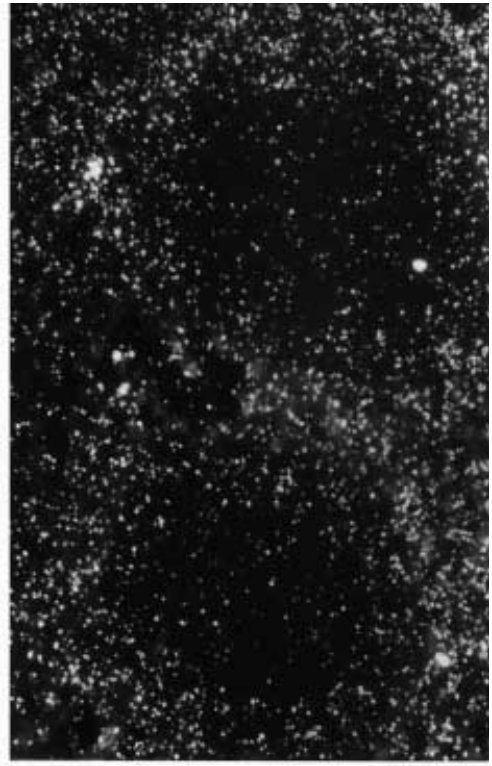

C

Figure 2 Lightfield (a) and darkfield (b and c) illumination of serial sections of two $0.4 \mathrm{~mm}$ diameter antral follicles probed with an IGF-II (b) and IGF-I (c) antisense riboprobe. The bar represents $180 \mu \mathrm{m}$. $\mathrm{t}$ and g represent theca and granulosa respectively.

mixed model, allowing for variation due to culture and different pools of cells (random effects). The effect of follicle size and health status on the intensity of the in situ hybridization signal was determined by ANOVA.

\section{Results}

Expression of IGF-I and -II and type 1 IGF receptor $m R N A$ in vivo

mRNA encoding IGF-II was expressed in theca tissue in follicles from around the stage of antrum development up to ovulation (Fig. 1). No expression was detected in granulosa tissue. There was no difference $(P>0 \cdot 05)$ in expression of IGF-II mRNA in small (1-4 mm), medium $(4-8 \mathrm{~mm})$ or large $(>8 \mathrm{~mm})$ healthy antral follicles. During the development of atresia there was a decrease $(P<0.001)$ in the abundance of IGF-II mRNA in theca tissue (results not shown).

We were unable to detect mRNA encoding IGF-I in granulosa tissue in any of the follicles examined. Very low expression was detected in the theca externa of healthy antral follicles (Fig. 2). Low expression was also occasionally detected in connective tissue surrounding some follicles (results not shown).

Expression of mRNA encoding type 1 IGF receptor mRNA was detected in granulosa and theca cells from both preantral and antral follicles (Fig. 3). Expression was greater in granulosa cells compared with theca tissue and decreased $(P<0.001)$ during the development of atresia (results not shown). During antral follicle growth there was no difference $(P>0 \cdot 05)$ in the expression of mRNA encoding type 1 IGF receptor between small (1-4 mm), medium $(4-8 \mathrm{~mm})$ or large $(>8 \mathrm{~mm})$ healthy follicles. Type 1 IGF receptor mRNA was also detected in oocytes from preantral and antral follicles.

\section{Expression of IGF-I and -II $m R N A$ in large (>15 mm) follicles}

The expression of mRNA encoding IGF-I and -II was measured in large follicles at defined stages of the oestrous cycle. The results presented in Fig. 4 shows the expression in a $19 \mathrm{~mm}$ diameter, dominant follicle on day 20 of the oestrous cycle. IGF-II mRNA was restricted to theca tissue. mRNA encoding IGF-I was not detected in either granulosa or theca tissue. Similar patterns of expression (results not shown) were observed with ovaries collected on day 14 (18 mm diameter; atretic follicle), day 16 (15 mm diameter; healthy follicle) and day 18 (15 $\mathrm{mm}$ diameter; healthy follicle) of the oestrous cycle as well as $48 \mathrm{~h}$ after prostaglandin treatment $(15 \mathrm{~mm}$ diameter follicle).

\section{Steroid production by cultured granulosa and theca cells}

In granulosa cell cultures oestradiol production (Fig. 5a) was higher $(P<0 \cdot 01)$ after 4 days in the presence of $1 \mathrm{ng}$ 


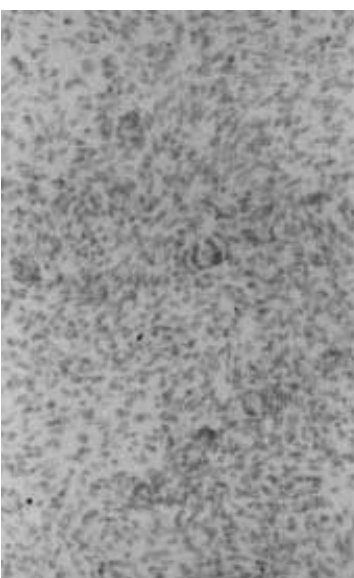

a

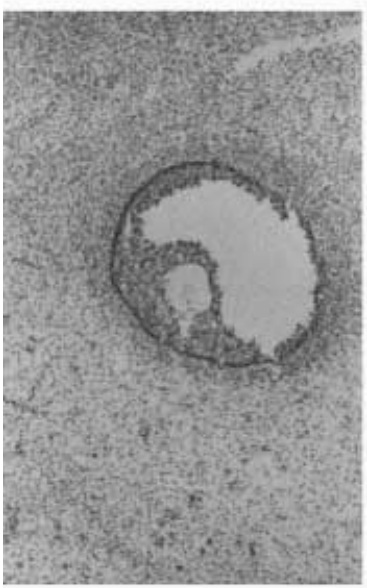

d

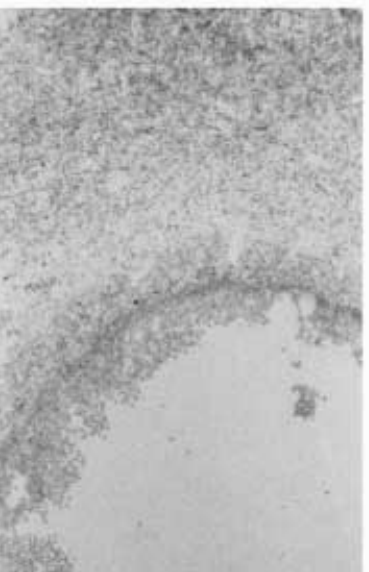

$\mathrm{g}$

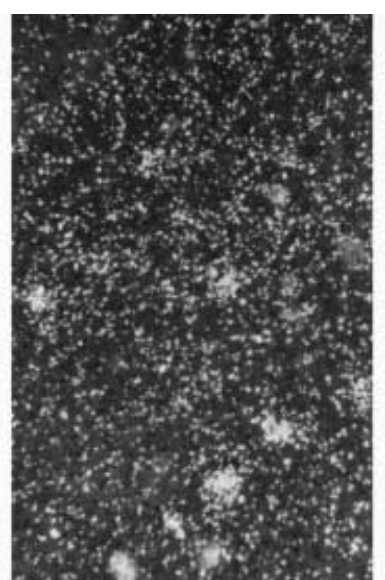

$\mathrm{b}$

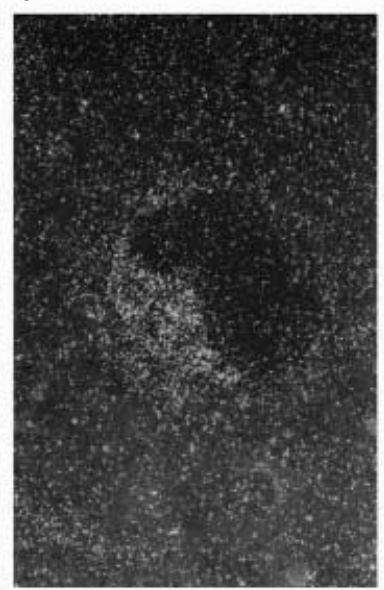

e

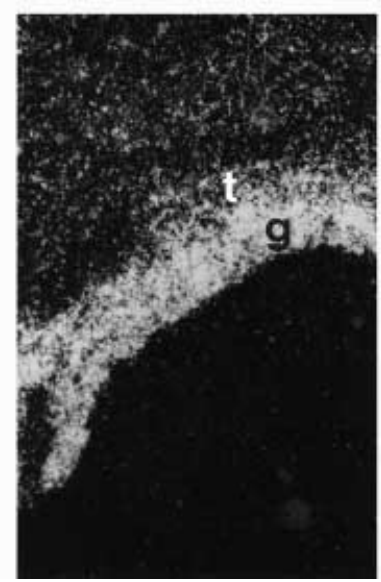

$\mathrm{h}$

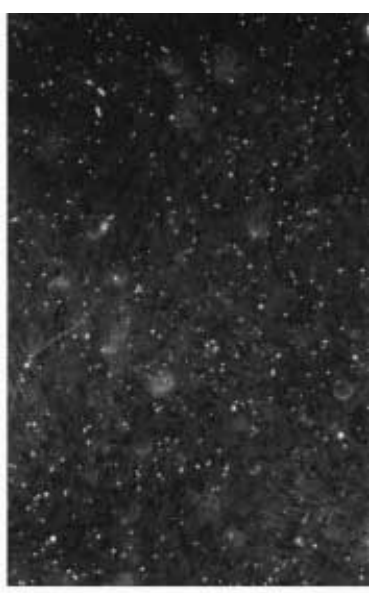

c

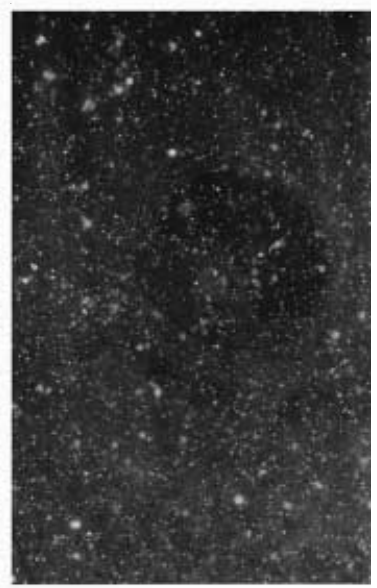

f

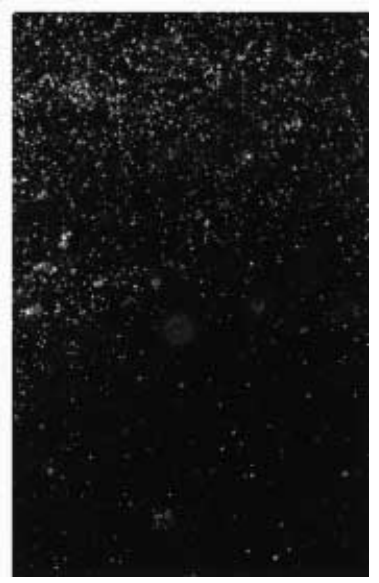

i

Figure 3 Lightfield (a, d and g) and darkfield (b, c, e, f, h and i) illumination of ovarian sections probed with a type 1 IGF receptor antisense $(b$, e and $h$ ) and sense (c, $f$ and i) riboprobe. IGF receptor mRNA expression is shown in granulosa cells of a group of primary follicles $(\mathrm{a}-\mathrm{c})$, in granulosa tissue, theca tissue and oocyte of a $0.3 \mathrm{~mm}$ diameter antral follicle $(\mathrm{d}-\mathrm{f})$ and in granulosa and theca tissue of a $15 \mathrm{~mm}$ diameter antral follicle (g-i). The bar represents $180 \mu \mathrm{m}$ $(\mathrm{a}-\mathrm{f})$ and $450 \mu \mathrm{m}(\mathrm{g}-\mathrm{i}) . \mathrm{t}$ and $\mathrm{g}$ represent theca and granulosa respectively. 

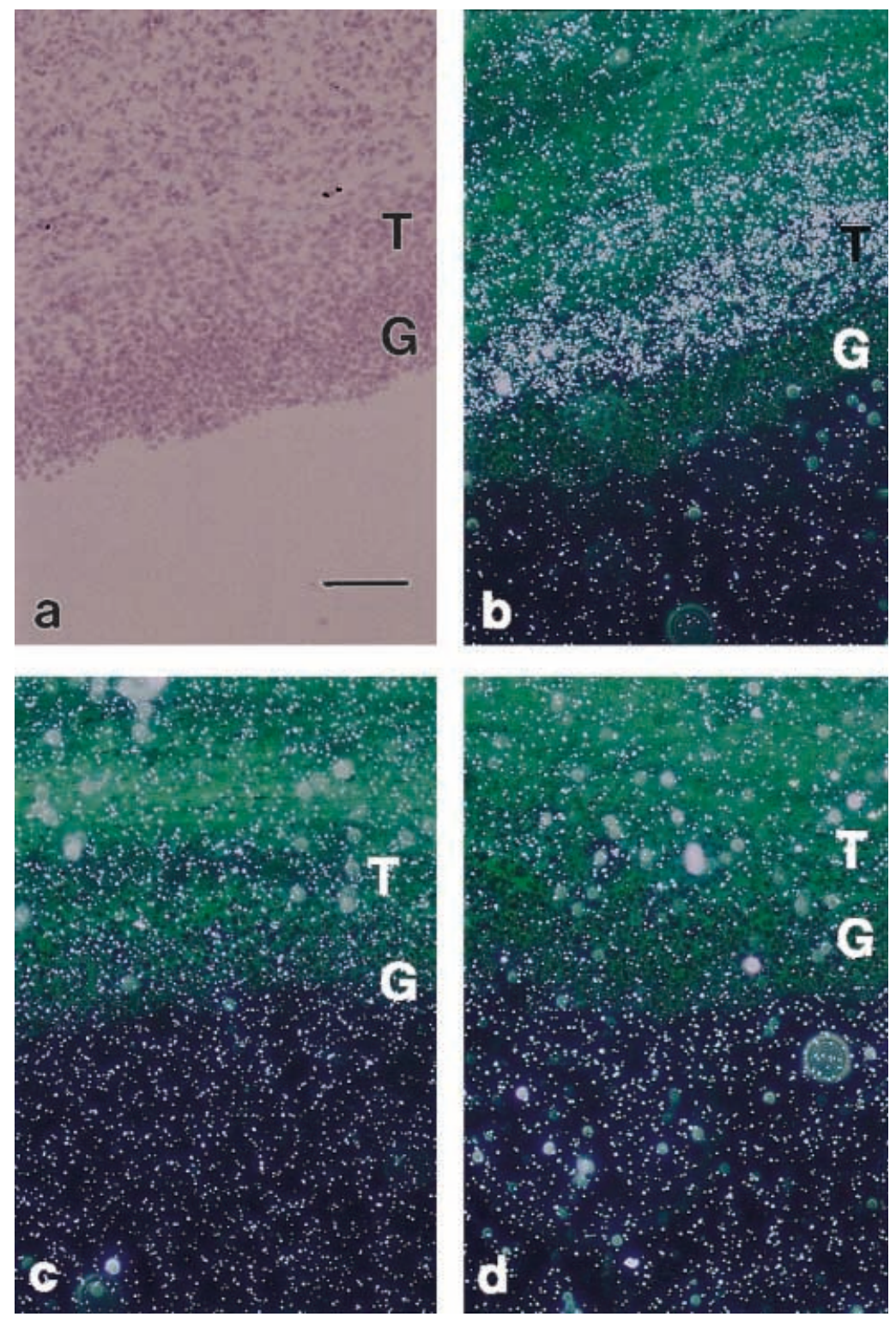

Figure 4 Lightfield (a) and darkfield (b-d) illumination of serial sections of an ovulatory follicle (19 mm diameter) probed with an IGF-II (b) and IGF-I (c) antisense and IGF-I sense (d) riboprobe. The bar represents $180 \mu \mathrm{m}$. T and G represent theca and granulosa respectively.

$\mathrm{FSH} / \mathrm{ml}$ compared with cultures in the absence of FSH. In the presence of $50 \mathrm{ng} \mathrm{FSH} / \mathrm{ml}$, oestradiol concentrations were lower $(P<0 \cdot 01)$ relative to the culture incubated in the presence of $1 \mathrm{ng} \mathrm{FSH} / \mathrm{ml}$. In contrast $50 \mathrm{ng} \mathrm{FSH} / \mathrm{ml}$ increased $(P<0 \cdot 01)$ the amount of progesterone in the culture medium (Fig. 5b). LH $(100 \mathrm{ng} / \mathrm{ml})$ increased $(P<0 \cdot 05)$ both oestradiol (Fig. 5c) and progesterone (Fig. 5d) production by granulosa cells after 4 days of culture and may in part be due to FSH contamination of the LH preparation $(<0.5 \%$ by weight).
In theca cell cultures $\mathrm{LH}(100 \mathrm{ng} / \mathrm{ml})$ increased $(P<0 \cdot 01)$ both androstenedione (Fig. 6a) and progesterone (Fig. 6b) production after 4 days of culture.

Expression of $m R N A$ encoding IGF-I and -II in granulosa and theca cells in culture

mRNA encoding IGF-I and -II in the granulosa and theca cell cultures characterized in the previous section was detected by RT-PCR. Representative results from three 

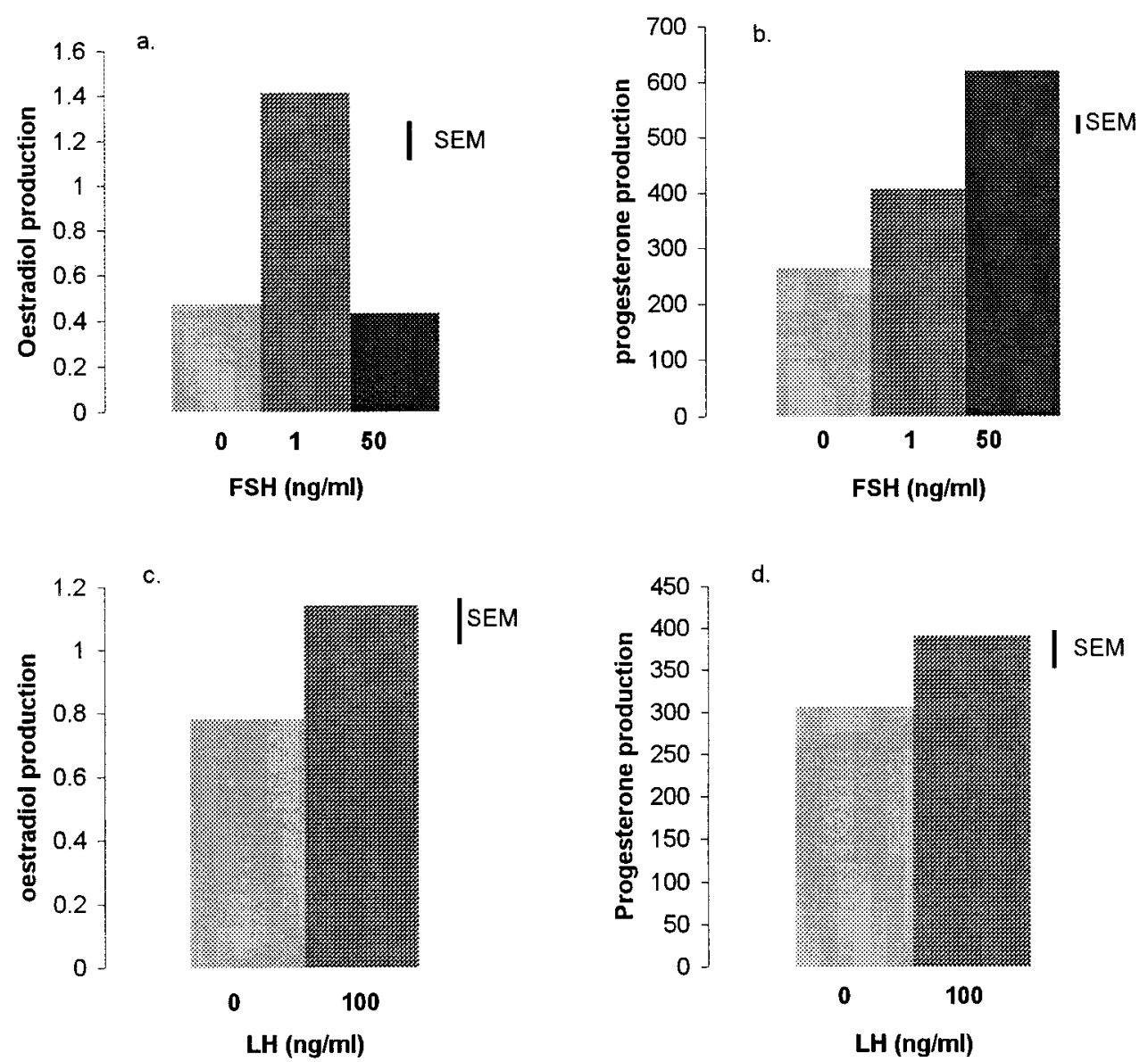

Figure 5 Oestradiol- $17 \beta$ (a and c) and progesterone ( $b$ and d) production ( $\mathrm{ng} / 10^{6}$ cells per $48-96 \mathrm{~h}$ ) by granulosa cells cultured in the presence of testosterone $(0 \cdot 1 \mu \mathrm{mol} / \mathrm{l})$, LR3-IGF-I $(10 \mathrm{ng} / \mathrm{ml})$, insulin $(10 \mathrm{ng} / \mathrm{ml})$ and $\mathrm{FSH}(0,1$ and $50 \mathrm{ng} / \mathrm{ml}$ ) (a and b) or in the presence and absence of $\mathrm{LH}$ (c and d). The bar represents a pooled S.E.M. obtained from two replicate measurements of three cultures.

separate experiments are shown in Figs 7 and 8. Specific primers for IGF-I and -II amplified cDNAs from RNA isolated from theca cells (Figs 7 and 8 respectively) both before and after culture and in the presence or absence of LH $(100 \mathrm{ng} / \mathrm{ml})$. Using RNA isolated from granulosa cells, amplification of cDNA was observed with IGF-II specific primers (Fig. 8); however, only very low amounts of amplified cDNA was detected with the IGF-I specific primers (Fig. 7). FSH had no effect on the expression of mRNA encoding IGF-I or -II in the cultures described here (results not shown).

\section{IGF-I production by granulosa cell cultures}

We were unable to detect significant amounts of immunoreactive IGF-I in granulosa cell conditioned medium even after 10-fold concentration using AmiconCentricon YM-3 membranes, molecular weight cut off
$3 \times 10^{3}$ (Millipore UK Ltd, The Boulevard, Blackmore Lane, Watford, Hertfordshire, UK).

\section{Immunohistochemical localization of IGF-I in the bovine ovary}

Immunoreactive IGF-I was located in endothelial cells of the ovarian vasculature (Fig. 9). We were unable to detect staining in granulosa or theca cells throughout follicular development.

\section{Discussion}

The principal aim of this study was to describe the spatial and temporal changes in the expression of mRNAs encoding IGF-I, IGF-II and the type 1 IGF receptor in granulosa and theca tissue from follicles at different stages 

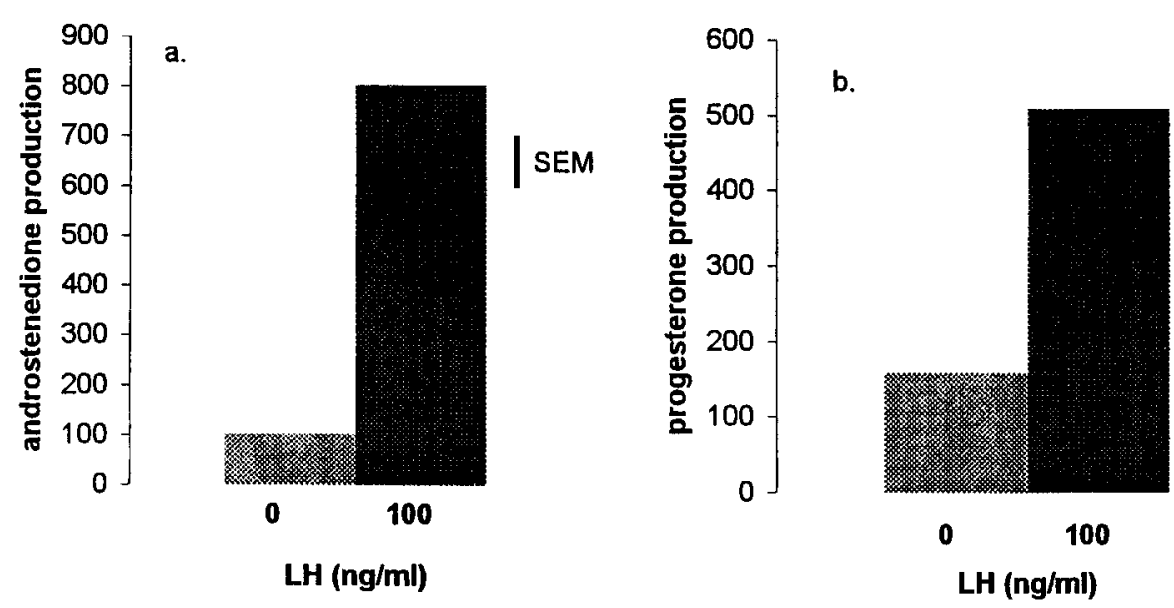

Figure 6 Androstenedione (a) and progesterone (b) production ( $\mathrm{ng} / 10^{6} \mathrm{cell}$ per $48-96 \mathrm{~h}$ ) by theca cells cultured in the presence of LR3-IGF-I $(10 \mathrm{ng} / \mathrm{ml})$ and insulin $(10 \mathrm{ng} / \mathrm{ml})$ in the presence and absence of LH $(100 \mathrm{ng} / \mathrm{ml})$. The bar represents a pooled S.E.M. obtained from two replicate measurements of three cultures.

of development in the bovine ovary. The work follows on from an earlier study describing IGFBP-2 and -4 mRNA expression in bovine follicles (Armstrong et al. 1998b) and together they provide a more comprehensive description of the anatomy of the bovine ovarian follicular IGF system.

Analysis of the expression pattern for mRNA encoding IGF-II indicated that this ligand was expressed in theca tissue in follicles from around the time of antrum formation up to ovulatory sized follicles. No expression of mRNA encoding IGF-II was detected in granulosa tissue at any stage of follicular development. This spatial distribution is similar to that described in sheep, rats and pigs (Armstrong \& Webb 1997). However, the timing of the onset of IGF-II mRNA expression in developing follicles is earlier in cows (around the time of antrum formation) than in pigs (Yuan et al. 1996).
The factors involved in switching on theca IGF-II mRNA expression are unknown. Theca cells surround the granulosa cells prior to antrum formation and express LH receptor mRNA at this early stage of development $(\mathrm{Xu}$ et al. 1995a, Bao \& Garverick 1998). In contrast, significant aromatase expression in granulosa cells only becomes apparent in follicles $>4 \mathrm{~mm}$ in diameter. Expression of mRNA encoding steroidogenic enzymes ( $\mathrm{P} 450_{\mathrm{scc}}$, $\mathrm{P} 450_{17 \alpha \mathrm{HOase}}$ and $\mathrm{P} 450_{\text {lyase }}$ ) is first detected in theca tissue of preantral follicles and their expression increases during antrum formation (Xu et al. 1995b, Boa \& Garverick 1998). The expression of mRNA encoding IGF-II in theca cells in early antral follicles can therefore be correlated with the acquisition of $\mathrm{LH}$ receptors on theca cell plasma membranes and their ability to produce androgen. Since IGF-I has been shown to increase LH receptor

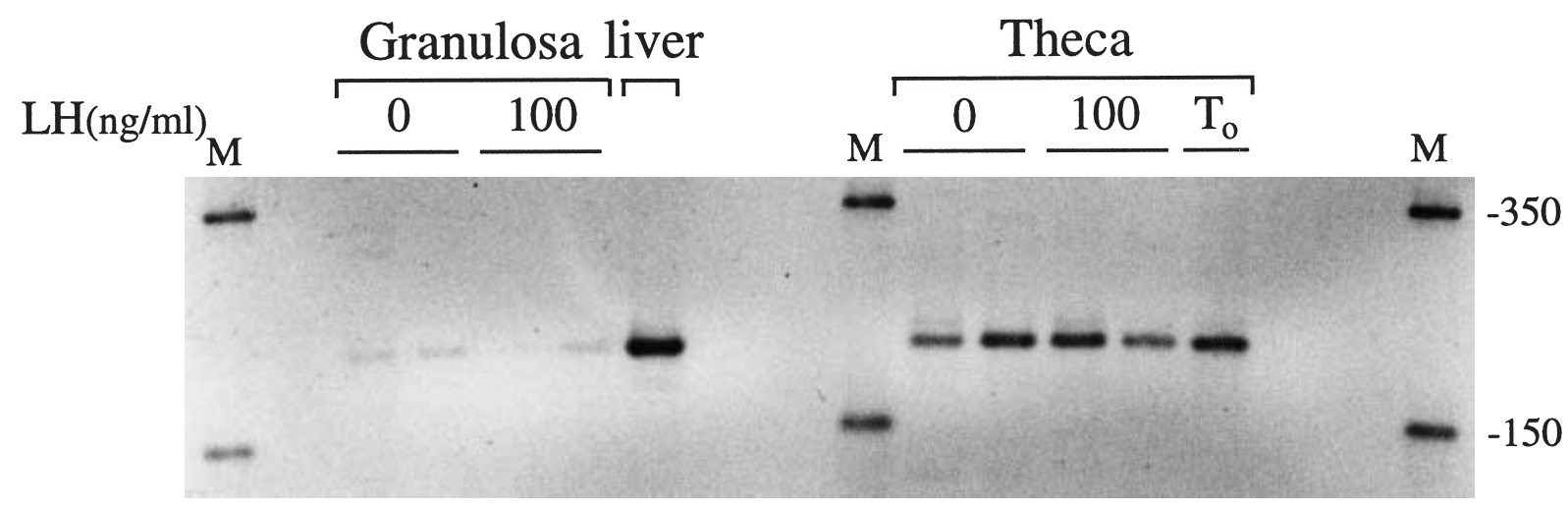

Figure 7 Effect of 0 or $100 \mathrm{ng} / \mathrm{ml}$ of LH on IGF-I mRNA expression by bovine granulosa and theca cells at the start of culture $\left(\mathrm{T}_{\mathrm{o}}\right)$ and after $96 \mathrm{~h}$ of culture. Hepatic mRNA was used as a positive control. M represents the marker lane, the size of the markers (nucleotide number) are shown on the right of the figure. 


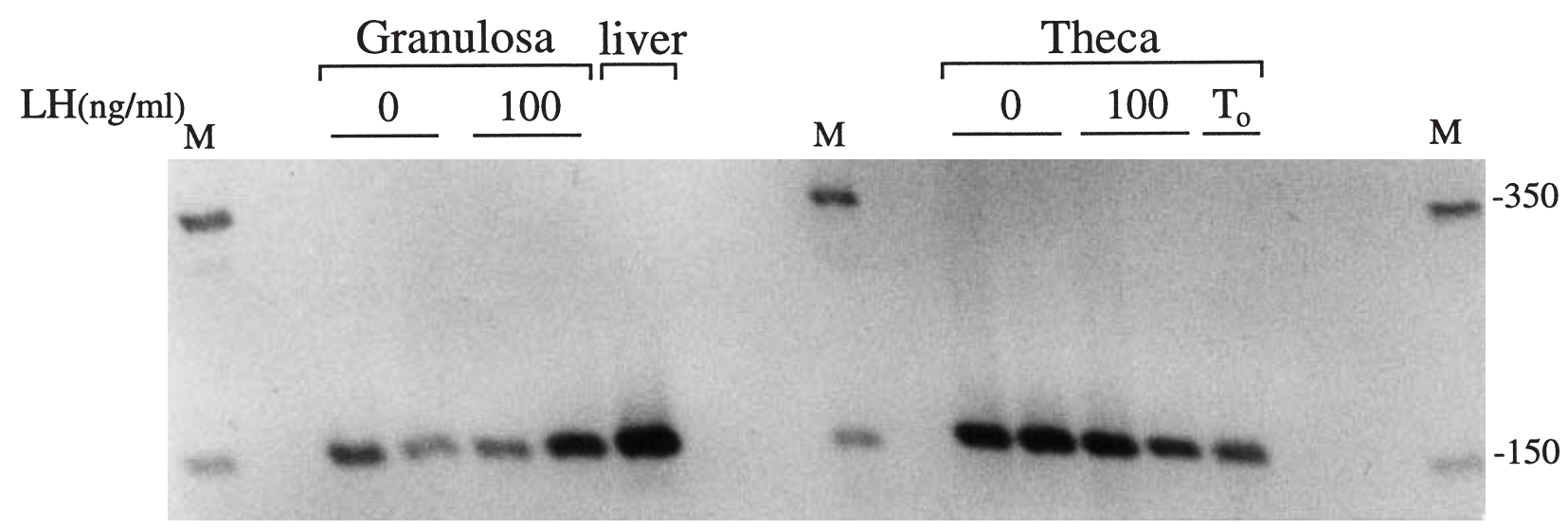

Figure 8 Effect of 0 or $100 \mathrm{ng} / \mathrm{ml}$ of LH on IGF-II mRNA expression by bovine granulosa and theca cells at the start of culture ( $\mathrm{T}_{\mathrm{o}}$ ) and after $96 \mathrm{~h}$ of culture. Hepatic mRNA was used as a positive control. M represents the marker lane, the size of the markers (nucleotide number) are shown on the right of the figure.

mRNA expression in rat theca cells (Magoffin \& Weitsman 1994) and LH receptor number in bovine theca cells (Stewart et al. 1995) it can be speculated that in ruminants in vivo IGF-II takes the place of IGF-I and regulates the timing of the onset of $\mathrm{LH}$ receptor expression in theca tissue via an autocrine mechanism.

IGF-I mRNA was detected in very low amounts in theca tissue from healthy antral follicles. The low amounts of mRNA encoding IGF-I detected in theca tissue is probably associated with the vascular endothelial cells within this tissue, a cell type that is known to express mRNA encoding components of the IGF system. Using immunohistochemistry we confirmed the presence of IGF-I immunoreactivity in the ovarian vasculature. Our in situ hybridization data failed to detect the presence of IGF-I mRNA in granulosa tissue at any stage of development. These data support the results of Perks et al. (1995, 1999) in sheep and cattle, but are at odds with those of Leewenburg et al. (1995) in sheep and Yuan et al. (1998) in cattle who have demonstrated the presence of mRNA encoding IGF-I in granulosa cells from both subordinate and dominant follicles. Previous work using bovine granulosa cell cultures (Spicer et al. 1993, Spicer \& Echternkamp 1995) also detected IGF-I mRNA.

The differences in IGF-I mRNA expression patterns between laboratories has been explained previously by differences in the sensitivity of probes used in the different studies. In this case, however, the IGF-I probe used in the present study and that described by Yuan et al. (1998) was the same. Nevertheless, despite the differences in abundance of IGF-I mRNA detected between laboratories, the results of Yuan et al. (1998) also show that IGF-II mRNA expression is significantly greater than that of IGF-I and support our conclusion that IGF-II is the major intrafollicular IGF ligand regulating the growth of bovine antral follicles.
We further examined the expression of mRNAs encoding IGF-I and -II in bovine granulosa and theca cell cultures using RT-PCR. The detection of IGF-I mRNA in cultured theca cells is probably a reflection of the cellular heterogeneity of this tissue. The detection of IGF-II mRNA as well as low levels of IGF-I mRNA in total RNA extracts from granulosa cells may indicate contamination of this culture with theca cells. Alternatively luteinization of granulosa cells could switch on IGF-II mRNA expression. In support of this latter conclusion is our recent result demonstrating expression of IGF-II mRNA in a subset of large luteal cells in sections of early bovine corpora lutea (Woad et al. 1998). These in vitro results highlight the need for care when interpreting PCR results obtained using granulosa and theca cell cultures. Minor contamination with other cell types and/or the spontaneous luteinization of a proportion of the cultured cells can seriously distort the results from the actual situation observed in vivo.

Further evidence supporting our observation on the lack of IGF-I mRNA expression in bovine granulosa cells in vivo is the absence of IGF-I immunoreactivity in granulosa cell conditioned medium. This supports results from an earlier study that also failed to detect IGF-I immunoreactivity in granulosa cell culture medium (Gutierrez et al. 1997b). IGF-I production by granulosa cells has been reported (Spicer et al. 1993); however, in this case, the interpretation of the results were compromised because measurements were carried out on acidethanol extracted samples. We have recently shown that a similar procedure fails to remove all the IGFBPs from granulosa cell conditioned media resulting in false positive results (Gutierrez et al. 1997b). Alternatively assay sensitivity may account for these discrepancies.

Type 1 IGF receptor mRNA was expressed in granulosa tissue from preantral and antral follicles. 

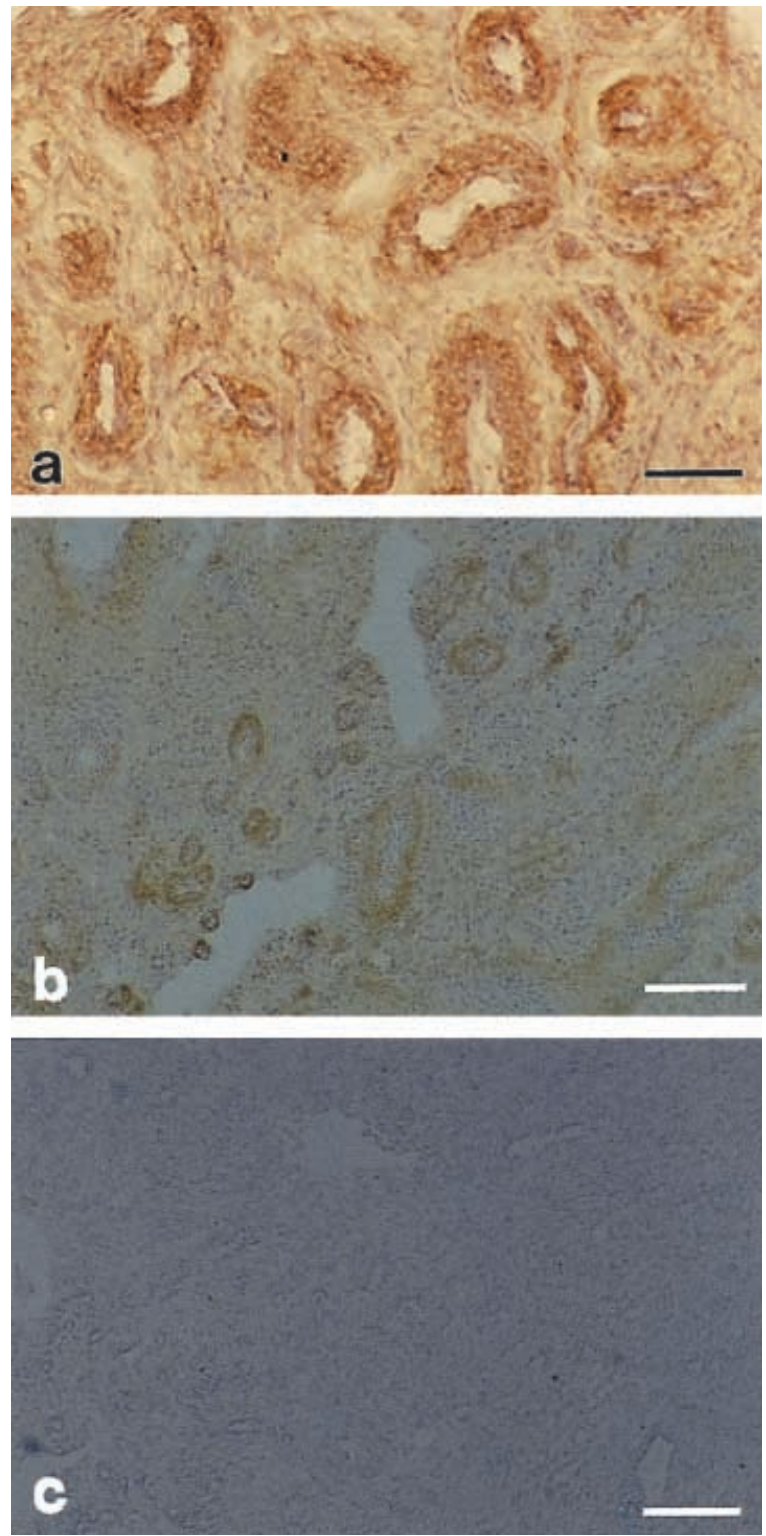

Figure 9 Bovine ovarian sections incubated with an antibody raised against human recombinant IGF-I in the absence ( $\mathrm{a}$ and $\mathrm{b}$ ) and presence (c) of exogenous IGF-I. Bar represents $180 \mu \mathrm{m}$ (a) and $450 \mu \mathrm{m}$ ( $b$ and $c)$.

Expression was also detected in theca tissue from antral follicles but this was always significantly less than in granulosa tissue from the same follicle. In addition, binding of IGF-I to preantral bovine follicles has been described by Wandji et al. (1992). Although the type 1 receptor binds IGF-II at a lower affinity than IGF-I we hypothesize that since IGF-II is the major intrafollicular IGF ligand, local concentrations of IGF-II within follicular tissue in vivo will be high enough to result in binding to the type 1 receptor and activate the second messenger system.
Type 1 IGF receptor expression was demonstrated in follicles of all sizes even though expression of IGF-II mRNA was not apparent in theca tissue until around the time of antrum formation. We propose, therefore, that preantral follicles are regulated by IGFs from the circulation, i.e. through endocrine mechanisms, whereas in antral follicles intrafollicular as well as endocrine mechanisms are probably involved in the IGF regulation of follicle development. Experiments described by Gong et al. (1993) provide evidence supporting an endocrine role for IGF-I for the regulation of follicle growth. The responsiveness of preantral follicles towards IGF-I has recently been demonstrated in vitro (Gutierrez et al. 1997c). In this case physiological concentrations of IGF-I in the culture medium increase the growth rate of preantral follicles. In the pig such an endocrine mechanism for the regulation of preantral follicle growth is not necessary since in this species granulosa cells of preantral follicles have been shown to express mRNA encoding IGF-I (Yuan et al. 1996).

Quantitative analysis of the expression of mRNA encoding IGF-II in theca and type 1 IGF receptor in bovine granulosa tissue indicated there were no significant changes in the level of their expression during follicle development after antrum formation. In contrast to these observations, Yuan et al. (1998) described a significant increase in IGF-II mRNA expression in dominant compared with subordinate follicles. This probably reflects differences in experimental design between the two studies in that the results described here were primarily obtained using abattoir material whereas Yuan et al. (1998) collected ovaries at precise times throughout the first wave of follicle growth after oestrus synchronization.

The results described here when combined with our previous study concerning the expression of mRNA encoding IGFBP-2 and -4 (Armstrong et al. 1998b) confirm the existence of a complete intrafollicular IGF system within bovine antral follicles, i.e. the ability to produce IGF ligand, the presence of receptors to mediate the biological actions of IGFs and the production of IGFBPs to regulate IGF bioavailability. These two studies have highlighted two major changes occurring within the ovarian IGF system during bovine follicle growth. The first is a switch from a total endocrine dependence towards IGFs in preantral follicles to a combination of intrafolliclular and endocrine mechanisms in antral follicles. The second is an increase in bioavailability of IGFs in dominant follicles arising from a decrease in the expression of mRNA encoding IGFBP-2 (Armstrong et al. 1998b).

In conclusion, our results support the hypothesis that theca-derived IGF-II is the major intraovarian IGF ligand produced by bovine antral follicles. The expression of mRNA encoding type 1 IGF receptor in granulosa cells from preantral follicles before the developmental stage when IGF-II mRNA is expressed indicates an endocrine role for IGFs in regulating preantral follicle growth. 


\section{Acknowledgements}

This work was supported by a Biotechnology and Biological Sciences Research Council Core Strategic Grant, the Ministry of Agriculture, Fisheries and Food (grant number DS0206) and by the Ministry of Agriculture Fisheries and Food and the Milk Development Council under the Link Sustainable Livestock Production Programme (grant LK0605). The British Council and CONACYT, Mexico supported CGG. A L G was supported by the Royal Society, UK and KJW was supported by the MRC.

\section{References}

Abbot AM, Bueno R, Pedrini MT, Murray JM \& Smith RJ 1992 Insulin-like growth factor 1 receptor gene structure. Journal of Biological Chemistry 267 10759-10763.

Adashi EY 1994 Growth factors and ovarian function: the IGF-I paradigm. Hormone Research 42 44-48.

Adashi EY \& Roban RM 1992 Intraovarian regulation. Peptidergic signalling systems. Trends in Endocrinology and Metabolism 3 243-248.

Armstrong DG \& Webb R 1997 Ovarian follicular dominance: the role of intraovarian growth factors and novel proteins. Reviews of Reproduction 2 139-146.

Armstrong DG, Duclos MJ \& Goddard C 1990 Biological activity of insulin-like growth factor-I purified from chicken serum. Domestic Animal Endocrinology 7 383-393.

Armstrong DG, Gutierrez CG, Woad KJ, Baxter G, Hogg CO \& Webb R 1998a The anatomy of the bovine ovarian IGF system. Journal of Endocrinology 156 Abstract No. P264.

Armstrong DG, Baxter G, Gutierrez CG, Hogg CO, Glazyrin AL, Campbell BK, Bramley TA \& Webb R 1998 b Insulin-like growth factor binding protein -2 and -4 mRNA expression in bovine ovarian follicles: effect of gonadotropins and developmental status. Endocrinology 139 2146-2154.

Bao B \& Garverick HA 1998 Expression of steroidogenic enzyme and gonadotropin receptor genes in bovine follicles during ovarian follicle waves: a review. Journal of Animal Science 76 1903-1921.

Brown WM, Dziegielewska KM, Foreman RC \& Saunders NR 1990 The nucleotide and deduced amino acid sequence of insulin-like growth factor-II cDNAs from adult bovine and fetal sheep liver. Nucleic Acids Research 184614.

Campbell BK, Scaramuzzi RJ \& Webb R 1995 Control of antral follicle development and selection in sheep and cattle. Journal of Reproduction and Fertility 49 335-350.

Campbell BK, Baird DT \& Webb R 1998 Effect of dose of LH on androgen production and luteinization of ovine theca cells cultured in a serum-free system. Journal of Reproduction and Fertility $\mathbf{1 1 2}$ 69-77.

Corrie JET, Hunter WM \& MacPherson JS 1981 A strategy for radioimmunoassay of plasma progesterone with the use of a homologous site ${ }^{125}$ I-labelled radioligand. Clinical Chemistry 27 594-599.

Fotsis T, Murphy C \& Gannon F 1990 Nucleotide sequence of the bovine insulin-like growth factor-I (IGF-I) and its IGF-IA precursor. Nucleic Acids Research 186761.

Giudice LC 1992 Insulin-like growth factors and ovarian development. Endocrine Reviews 13 641-669.

Gong JG, Bramley TA \& Webb R 1993 The effect of recombinant bovine somatotropin on ovarian follicular growth and development in heifers. Journal of Reproduction and Fertility 97 247-254.

Gutierrez CG, Campbell BK \& Webb R 1997a Development of a long-term bovine granulosa cell culture system: induction and maintenance of estradiol production response to follicle-stimulating hormone and morphological characteristics. Biology of Reproduction 56 608-616.

Gutierrez CG, Campbell BK, Armstrong DG \& Webb R $1997 b$ Insulin-like growth factor-I (IGF-I) production by bovine granulosa cells in vitro and peripheral IGF-I measurement in cattle serum: an evaluation of IGFBP extraction protocols. Journal of Endocrinology 153 231-240.

Gutierrez CG, Ralph JH, Wilmut I \& Webb R 1997c Follicle growth and antrum formation of bovine preantral follicles in long-term in vitro culture. Journal of Reproduction and Fertility Abstract Series No. 19, Abstract No. 31.

Hammond JM, Mondschein JS, Samaras SE \& Canning SF 1991 The ovarian insulin-like growth factors, a local amplification mechanism for steroidogenesis and hormone action. Journal of Steroid Biochemistry and Molecular Biology 40 411-416.

Leewenberg BR, Hurst PR \& McNatty KP 1995 Expression of IGF-I mRNA in the ovine ovary. Journal of Molecular Endocrinology 15 251-258.

Magoffin DA \& Weitsman SR 1994 Insulin-like growth factor-I regulation of luteinizing hormone (LH) receptor messenger ribonucleic acid expression and LH-stimulated signal transduction in rat ovarian theca interstitial cells. Biology of Reproduction 51 766-775.

Monget P \& Monniaux D 1995 Growth factors and the control of folliculogenesis. Journal of Reproduction and Fertility 49 321-333.

Perks CM, Dennining-Kendall PA, Gilmour RS \& Wathes DC 1995 Localization of messenger ribonucleic acids for insulin-like growth factor I (IGF-I), IGF-II and the type 1 IGF receptor in the ovine ovary throughout the estrous cycle. Endocrinology 136 5266-5273.

Perks CM, Peters AR \& Wathes DC 1999 Follicular and luteal expression of insulin-like growth factors I and II and the type 1 IGF receptor in the bovine ovary. Journal of Reproduction and Fertility $116157-165$

Sneyers M, Kettman R, Massart S, Renaville R, Burny A \& Portetelle D 1991 Cloning and characterization of a cDNA encoding the beta-subunit of the bovine insulin-like growth factor-1 receptor. DNA Sequence 1 405-406.

Spicer LJ \& Echternkamp SE 1995 The ovarian insulin and insulinlike growth factor system with an emphasis on domestic animals. Domestic Animal Endocrinology 12 223-245.

Spicer LJ, Alpizar E \& Echternkamp SE 1993 Effects of insulin, insulin-like growth factor-I and gonadotropins on bovine granulosa cell proliferation, progesterone production, estradiol production and (or) insulin-like growth factor-I production in vitro. Journal of Animal Science 71 1232-1241.

Stewart RE, Spicer LJ, Hamilton TD \& Keefer BE 1995 Effects of insulin-like growth factor I and insulin on proliferation and on basal and luteinizing hormone-induced steroidogenesis of bovine theca cells: involvement of glucose and receptors for insulin-like growth factor I and luteinizing hormone. Journal of Animal Science $\mathbf{7 3}$ 3719-3731.

Tavakkol A, Simmen FA \& Simmen RCM 1988 Porcine insulin-like growth factor-I (pIGF-I): complementary deoxyribonucleic acid cloning and uterine expression of messenger ribonucleic acid encoding evolutionary conserved IGF-I peptides. Molecular Endocrinology 2 674-681.

Wandji S, Pelletier G \& Sirard M 1992 Ontogeny and cellular localization of ${ }^{125} \mathrm{I}$-labeled insulin-like growth factor-I, ${ }^{125}$ I-labeled FSH and ${ }^{125}$ I-labeled human chorionic gonadotrophin binding sites in ovaries from bovine fetuses and neonatal calves. Biology of Reproduction 47 814-822.

Webb R \& Armstrong DG 1998 Control of ovarian function; effect of local interactions and environmental influences on follicular turnover in cattle: a review. Livestock Production Science 53 95-112.

Webb R, Baxter G, McBride D, Nordblom GD \& Shaw MPK 1985 The measurement of testosterone and estradiol-17 $\alpha$ using iodinated tracers and incorporating an affinity chromatography extraction procedure. Journal of Steroid Biochemistry 23 1043-1051. 
Woad KJ, Armstrong DG, Baxter G, Gutierrez CG, Hogg CO, Bramley TA \& Webb R 1998 Comparison of the insulin like growth factor system in natural and induced bovine corpora lutea. Journal of Reproduction and Fertility Abstract Series No. 22, Abstract No. 29.

Xu ZZ, Garverick HA, Smith GW, Smith MF, Hamilton SA \& Youngquist RS 1995a Expression of follicle-stimulating hormone and luteinizing hormone receptor messenger ribonucleic acids in bovine follicles during the first follicular wave. Biology of Reproduction 53 951-957.

Xu ZZ, Garverick HA, Smith GW, Smith MF, Hamilton SA \& Youngquist RS 1995b Expression of messenger ribonucleic acid encoding cytochrome P450 side-chain cleavage, cytochrome P450 $17 \alpha$-hydroxylase, and cytochrome $\mathrm{P} 450$ aromatase in bovine follicles during the first follicular wave. Endocrinology 13 981-989.
Yuan W, Lucy M \& Smith MF 1996 Messenger ribonucleic acid for insulin-like growth factors-I and -II, insulin-like growth factor binding protein-2, gonadotropin receptors, and steroidogenic enzymes in porcine follicles. Biology of Reproduction 55 1045-1054.

Yuan W, Bao B, Garverick HA, Youngquist RS \& Lucy MC 1998 Follicular dominance in cattle is associated with divergent patterns of ovarian gene expression for insulin-like growth factor (IGF)-I, IGF-II and IGF binding protein-2 in dominant and subordinate follicles. Domestic Animal Endocrinology 15 55-63.

Received 22 September 1999

Accepted 17 November 1999 